\title{
INHIBITION BY 6-MERCAPTOPURINE OF POLYARTHRITIS INDUCED BY FREUND'S ADJUVANT
}

\author{
BY \\ J. L. KALLIOMÄKI, H. A. SAARIMAA, AND P. TOIVANEN \\ From the Departments of Medicine and Medical Microbiology, University of Turku, Finland
}

Formation of granuloma and production of antibodies in guinea-pigs receiving egg albumen with Freund's adjuvant may be suppressed by cortisone (Fischel, Kabat, Stoerk, Skolnick, and Bezer, 1954). The arthritis induced in rats by Freund's adjuvant may also be prevented by treatment with cortisone (e.g. Houssay and Frangione, 1961; Pearson, Wood, and Waksman, 1961), pyrazolidines, salicylates, and sodium aurothiomalate (Newbould, 1963).

Cortisone, for example, has nonspecific antiphlogistic properties, which cannot be excluded in evaluating the mechanism of the cortisone effect in the prevention of this adjuvant-induced arthritis.

There are numerous studies in the literature of the preventive effect of 6-mercaptopurine (6-MP) in the primary and secondary immune responses in skin and renal homografts, protein antigens, experimental allergic encephalomyelitis, and intramyocardial injections of streptococci (Schwartz, Stack, and Dameshek, 1958; Meeker, Condie, Weiner, Varco, and Good, 1959; Schwartz and Dameshek, 1959, 1960; Schwartz, Eisner, and Dameshek, 1959; Calne, 1960; Hoyer, Condie, and Good, 1960; Thomas, Morton, Crane, and Gardner, 1961; Zukoski, Lee, and Hume, 1961; Pierce and Varco, 1962; Laufer, Ginsburg, Gery, and Davies, 1963).

To obtain further information regarding the pathogenesis of the arthritis induced by Freund's adjuvant, the effect of 6-MP on the appearance of this experimental arthritis has been studied.

\section{Method}

Male rats (age 1 to 2 months; weight 240-340 g.) were used, eighteen in the group treated with 6-MP and seventeen controls. In the group treated with 6-MP three deaths occurred on the 12th or 13th day of the experiment; these three animals were excluded, the final number in this group thus being fifteen.

An adjuvant mixture containing $0.6 \mathrm{mg}$. dry, heatkilled Mycobacterum phlei in $0.1 \mathrm{ml}$. paraffin oil was injected intradermally into the medial tail of each animal in both groups.

A 0.5 per cent. water suspension of $6-\mathrm{MP}, 15 \mathrm{mg} . / \mathrm{kg}$. daily, was administered through a tube inserted into the stomach to each test animal. The administration of 6-MP was started 3 days before the injection of the adjuvant, and was continued during the whole experiment. The animals in the control group were given injections of the adjuvant only.

The animals were examined daily and joint involvement was evaluated by the visible swelling and redness of the joints, with the aid of an "arthrogram score", $0,1,2,3$. Figs 1 and 2 (opposite) show examples of joints without arthritis (Score 0 ) and with severe arthritic changes (Score 3).

On the 19th day after the injection of the adjuvant, a tuberculin test was performed by injecting $0.1 \mathrm{ml}$. of a $10^{-4}$ dilution of Tuberculin "GT" (Behringwerke AG) intradermally into the abdomen of all the animals. The reaction was evaluated 24 and 48 hours after the injection, and the result was considered positive when a swelling with a diameter of $\geq 4 \mathrm{~mm}$. developed at the site of the tuberculin injection. The animals were then killed. The whole experiment thus covered 21 days.

\section{Results}

The most important results are given in the Table (opposite). Arthritis developed in only four of the fifteen rats treated with 6-MP, but in fifteen of the seventeen controls. Delayed hypersensitivity of the tuberculin type developed in three of the four rats in the 6-MP group in which adjuvant arthritis had also developed. The tuberculin test was positive in eleven of the fifteen control rats which developed adjuvant arthritis. The differences between the two groups are statistically significant for each test. 


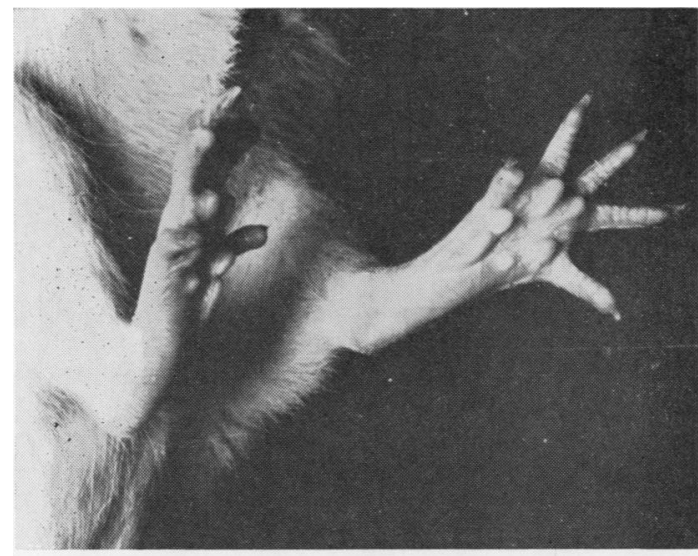

Fig. 1.-Unaffected joints, arthrogram score 0 (a rat of the 6-MP group).

TABLE

RESULTS OF TESTS IN EACH ANIMAL

\begin{tabular}{|c|c|c|c|c|c|}
\hline \multirow[b]{2}{*}{ Group } & \multirow[b]{2}{*}{$\begin{array}{l}\text { Rat } \\
\text { No. }\end{array}$} & \multicolumn{3}{|c|}{ Adjuvant Arthritis } & \multirow{2}{*}{$\begin{array}{c}\text { Tuberculin } \\
\text { Reaction } \\
\text { (mm. } \\
\text { diameter) }\end{array}$} \\
\hline & & $\begin{array}{c}\text { Time of } \\
\text { Onset } \\
\text { (days) }\end{array}$ & $\begin{array}{l}\text { No. of } \\
\text { Joints } \\
\text { Affected }\end{array}$ & $\begin{array}{c}\text { Arthro- } \\
\text { gram } \\
\text { Score }\end{array}$ & \\
\hline \multirow[t]{2}{*}{ 6-MP } & $\begin{array}{r}1 \\
2 \\
3 \\
4 \\
5 \\
6 \\
7 \\
8 \\
9 \\
10 \\
11 \\
12 \\
13 \\
14 \\
15\end{array}$ & $\begin{array}{l}\overline{14} \\
16 \\
\overline{17} \\
16 \\
\overline{-} \\
= \\
= \\
= \\
=\end{array}$ & $\begin{array}{l}0 \\
4 \\
3 \\
0 \\
2 \\
1 \\
0 \\
0 \\
0 \\
0 \\
0 \\
0 \\
0 \\
0 \\
0\end{array}$ & $\begin{array}{l}0 \\
3 \\
2 \\
0 \\
2 \\
1 \\
0 \\
0 \\
0 \\
0 \\
0 \\
0 \\
0 \\
0 \\
0\end{array}$ & $\begin{array}{l}5 \\
4 \\
\overline{12} \\
\overline{-} \\
\overline{-} \\
\overline{-} \\
\overline{-} \\
\overline{-} \\
-\end{array}$ \\
\hline & Mean & $15 \cdot 8$ & $2 \cdot 5$ & 2 & 7 \\
\hline \multirow[t]{2}{*}{ Control } & $\begin{array}{r}1 \\
2 \\
3 \\
4 \\
5 \\
6 \\
7 \\
8 \\
9 \\
10 \\
11 \\
12 \\
13 \\
14 \\
15 \\
16 \\
17\end{array}$ & $\begin{array}{l}16 \\
16 \\
19 \\
13 \\
16 \\
14 \\
14 \\
14 \\
\overline{16} \\
12 \\
12 \\
16 \\
19 \\
16 \\
14\end{array}$ & $\begin{array}{l}2 \\
4 \\
3 \\
4 \\
2 \\
1 \\
4 \\
2 \\
0 \\
1 \\
4 \\
4 \\
2 \\
0 \\
1 \\
3 \\
4\end{array}$ & $\begin{array}{l}1 \\
2 \\
1 \\
2 \\
1 \\
2 \\
3 \\
1 \\
0 \\
1 \\
2 \\
1 \\
1 \\
0 \\
1 \\
3 \\
1\end{array}$ & $\begin{array}{r}5 \\
5 \\
4 \\
4 \\
5 \\
4 \\
- \\
-4 \\
12 \\
8 \\
7 \\
4 \\
-\end{array}$ \\
\hline & Mean & $15 \cdot 1$ & $2 \cdot 7$ & $1 \cdot 5$ & \\
\hline
\end{tabular}

The arthritis which developed in four rats of the group treated with 6-MP did not differ from that observed in the control groups as regards average time of appearance ( 15.8 and $15 \cdot 1$ days), average number of arthritic joints $(2 \cdot 5$ and $2 \cdot 7)$ and average arthrogram score $(2$ and $1 \cdot 5)$.

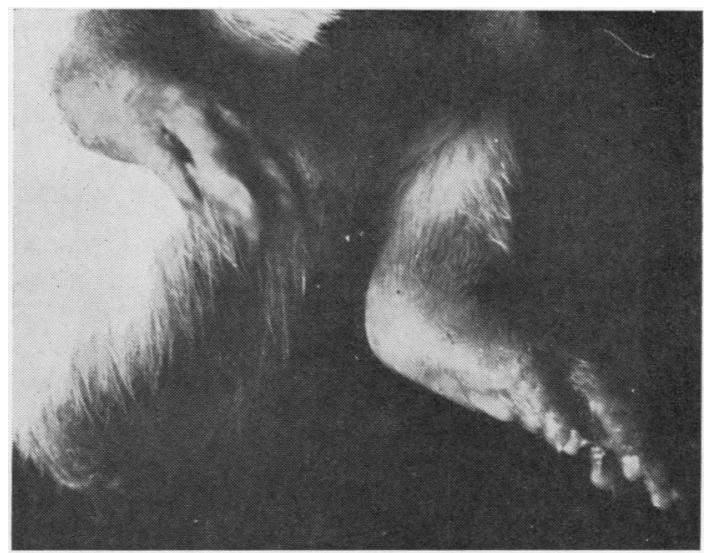

Fig. 2.-Affected joints, arthrogram score 3 (a rat of the control group).

\section{Discussion}

We consider that our results support the hypothesis that adjuvant arthritis is a form of delayed hypersensitivity reaction (e.g. Pearson and others, 1960; Waksman, Pearson, and Sharp, 1960). Simultaneous inhibition of the development of adjuvant arthritis and delayed dermal hypersensitivity of the tuberculin followed the administration of 6-MP. It has previously been demonstrated that the development of tuberculin hypersensitivity is suppressed in guinea-pigs treated with 6-MP (Hoyer, Hoyer, Good, and Condie, 1962). A tuberculin of human strain was used in our study, but Mellman and Barness (1962) state that tuberculins derived from a human strain of Mycobacterium or from nonphotochromogenic acid-fast bacilli are cross-reacting, and that many patients with chronic lung disease due to these atypical Mycobacteria react positively to PPD-tuberculin of human origin.

The relationship between adjuvant arthritis in rats and rheumatoid arthritis in man is not known. Our experiments may help to explain why alkylating agents have a favourable, suppressive effect on the inflammatory reactions of connective tissue diseases (e.g. Scherbel, Mackenzie, and Aldjian, 1963).

\section{Summary}

6-mercaptopurine significantly inhibits the development of adjuvant-induced arthritis and the dermal hypersensitivity reaction of the tuberculin type in rats.

\section{REFERENCES}

Calne, R. Y. (1960). Lancet, 1, 417.

Fischel, E. E., Kabat, E. A., Stoerk, H. C., Skolnick, M., and Bezer, A. E. (1954). J. Allergy, 25, 195. 
Houssay, R. H., and Frangione, B. (1961). "Atti del $\mathrm{X}$ congresso della Lega Internazionale contro il Reumatismo", vol. 2, p. 950.

Hoyer, L. W., Condie, R. M., and Good, R. A. (1960). Proc. Soc. exp. Biol. (N.Y.), 103, 205.

Hoyer, J. R., Hoyer, L. W., Good, R. A., and Condie, R. M. (1962). J. exp. Med., 116, 679.

Laufer, A., Ginsburg, I., Gery, I., and Davies, A. M. (1963). Path. Microbiol., 26, 263.

Meeker, W., Condie, R., Weiner, D., Varco, R. L., and Good, R. A. (1959). Proc. Soc. exp. Biol. (N. Y.), $102,459$.

Mellman, W. J., and Barness, L. A. (1962). Amer. J. Dis. Child., 104, 21.

Newbould, B. B. (1963). Brit. J. Pharmacol., 21, 127.

Pearson, C. M., Wood, F. D., and Waksman, B. H. (1961). "Atti del X congresso della Lega Internazionale contro il Reumatismo", vol. 2, p. 960.

Pierce, J. C., and Varco, R. L. (1962). Lancet, 1, 781.

Scherbel, A. L., Mackenzie, A. H., and Aldjian, M. (1963). Abstracts of Communications, "Fifth European Congress on Rheumatic Diseases, Stockholm", p. 179.

Schwartz, R., and Dameshek, W. (1959). Nature (Lond.), 183, 1682.

-_, - (1960). J. clin. Invest., 39, 952.

_-, Eisner, A., and Dameshek, W. (1959). Ibid., 38, 1394.

—, Stack, J., and Dameshek, W. (1958). Proc. Soc. exp. Biol. (N.Y.). 99, 164.
Thomas, A. N., Morton, D. L., Crane, J. T., and Gardner, R. E. (1961). Ibid., 107, 70.

Waksman, B. H., Pearson, C. M., and Sharp, J. T. (1960). J. Immunol., 85, 403.

Zukoski, C. F., Lee, H. M., and Hume, D. M. (1961). Surg. Gynec. Obstet., 112, 707.

Inhibition par la 6-mercaptopurine de la polyarthrite du rat provoquée par l'adjuvant de Freund

\section{RÉSUMÉ}

La 6-mercaptopurine inhibe appréciablement le développement de l'arthrite provoquée chez le rat par l'adjuvant de Freund; cette inhibition s'étend à la réaction cutanée d'hypersensibilité à la tuberculine.

Inhibición por la 6-mercaptopurina de la poliartritis provocada en ratas por el coadyuvante de Freund

\section{SUMARIO}

La 6-mercaptopurina inhibe significativamente el desarrollo de la artritis provocada en ratas por el coadyuvante de Freund; esta inhibición se extiende también a la reacción cutánea de hipersensibilidad a la tuberculina. 